\title{
Penghapusan Jaminan Fidusia Online Studi empiris di Kabupaten Badung
}

\author{
Viriyananta Gotama ${ }^{1}$
}

${ }^{11}$ Program Studi Magister (S2) Kenotariatan Fakultas Hukum Universitas Udayana, BaliIndonesia, E-mail:viriyanantag93@gmail.com

\begin{tabular}{l}
\hline Info Artikel \\
\hline Masuk: \\
Diterima : \\
Terbit: \\
Keywords : Fiduciary \\
guarantee, elimination of \\
fiduciary warranties, \\
creditors, debtors \\
\\
Kata kunci: Jaminan Fidusia \\
Penghapusan Jaminan \\
Fidusia, Kreditur, Debitur \\
Corresponding Author: \\
Penulis Pertama, E-mail: \\
viriyanantag93@ gmail.com \\
DoI :
\end{tabular}

\begin{abstract}
The registration of fiduciary guarantee is resolved by the process of elimination of fiduciary at the end of fiduciary guarantee, it is useful to restore the right of fiduciary for the object in which it is permitted. In order to do the process of elimination of fiduciary guarantee is less assertive, because it is a lot of lenders who do not do the elimination of fiduciary guarantee. The purpose of this writing is to analyse the elimination of fiduciary warranties. This study uses empirical legal research types with a statutory approach and empirical facts. The study showed that the role of notary in the implementation of fiduciary guarantee process is carried out but still many parties and debtors who do not do as stipulated in the law No. 42 year 1999 on Fiduciary Guarantee Article 25. In connection with the elimination of fiduciary warranties, Notary has a very important role, the party responsible for the elimination of fiduciary guarantees.
\end{abstract}

\begin{abstract}
\begin{tabular}{l} 
Abstrak \\
\hline Pendaftaran jaminan fidusia diselesaikan dengan proses \\
penghapusan jaminan fidusia pada saat berakhirnya \\
jaminan fidusia, proses tersebut berguna untuk \\
mengembalikan hak pemberi jaminan fidusia untuk \\
obyek yang di jaminkannya. Dalam peraturan untuk \\
melakukan proses penghapusan jaminan fidusia dirasa \\
kurang tegas, karena itu banyak pihak kreditur yang \\
tidak melakukan penghapusan jaminan fidusia. Tujuan \\
penulisan in i untuk menganalisis proses penghapusan \\
jaminan fidusia. Penelitian ini mengunakan jenis \\
penelitian hukum empiris dengan dengan pendekatan \\
perundang-undangan dan fakta empiris. Hasil studi \\
menunjukan bahwa peranan notaris dalam pelaksanaan \\
proses penghapusan jaminan fidusia sudah terlaksana \\
namun masih banyak pihak-pihak kreditur maupun \\
debitur yang tidak melakukan sebagaimana diatur dalam \\
Undang-Undang No. 42 Tahun 1999 tentang Jaminan \\
Fidusia Pasal 25 . Berkaitan dengan penghapusan jaminan \\
fidusia, Notaris memiliki peran yang sangat penting, pihak \\
yang bertugas untuk melakukan penghapusan jaminan \\
fidusia.
\end{tabular}
Abstrak penghapusan jaminan fidusia pada saat berakhirnya jaminan fidusia, proses tersebut berguna untuk melakukan proses penghapusan jaminan fidusia dirasa kurang tegas, karena itu banyak pihak kreditur yang penulisan ini untuk menganalisis proses penghapusan jaminan fidusia. Penelitian ini mengunakan jenis penelitian hukum empiris dengan dengan pendekatan perundang-undangan dan fakta empiris. Hasil studi menunjukan bahwa peranan notaris dalam pelaksanaan proses penghapusan jaminan fidusia sudah terlaksana debitur yang tidak melakukan sebagaimana diatur dalam Undang-Undang No. 42 Tahun 1999 tentang Jaminan Fidusia Pasal 25. Berkaitan dengan penghapusan jaminan fidusia, Notaris memiliki peran yang sangat penting, pihak fidusia.
\end{abstract}




\section{Pendahuluan}

Pulau Bali merupakan daerah yang terkenal dengan pariwisatanya, dimana terdapat banyak pengusaha dan masyarakat yang melakukan wirausaha sebagai penopang hidup sehari-hari. Dalam melakukan suatu wirausaha, modal adalah sesuatu yang dibutuhkan. Salah satu cara untuk mendaptkan penambahan modal usaha adalah melalui pengajuan kredit kepada perbankan ataupun lembaga pembiayaan lainnya. Sebagai salah satu contoh bidang usaha penunjang pariwisata di Bali adalah unit usaha penyewaan kendaraan bermotor, baik itu kendaraan roda dua ataupun kendaraan roda empat. Banyak pengusaha yang bergerak dalam bidang transportasi khususnya penyewaan kendaraan, yang mengalami kendala dalam penyediaan kendaraan, sedangkan disisi lain permintaan para wisatawan untuk dapat menyewa kendaraan-kendaraan tersebut selama mereka berlibur di Bali terus mengalami peningkatan, seiring meningkatnya jumlah wisatawan yang berlibur ke Bali. ${ }^{1}$

Bagi para pengusaha yang mempunyai cukup modal untuk memperbesar usahanya, peranan perbankan dan lembaga pembianyaan sangatlah penting, karena meraka dapat meberikan kredit untuk melakukan pembelian kendaraan, jaminan benda bergerak diatur dalam Undaang-Undaang Nomore 42 taahun 1999 tentang jaminan fidusia (selanjutnya disebut UU JFDS). Dalam Pasal 1 angka 1 UU JFDS, ditentukan pengertian fidusia adalah pengalihan hak kepunyaan suatu benda atas dasar mempercayai dengan aturan dimana benda tersebut tetap dalam kepunyaan pemilik benda, tetapi bukti kepemilikan benda tersebut yang akan di pakai sebagai jaminan untuk melakukan kredit. ${ }^{2}$

Jaminan fidusia lebih banyak peminatnya di masyarakat, walaupun terdapat proses penyerahan bukti kepunyaan benda tersebut atas dasar mempercayai dari pemberi fidusia kepada penerima fidusia, namun pada waktu yang bersamaan, pemberi fidusia masih dapat wewenang fisik dan menggunakan kendaraan tersebu, Frieda Husni Hasbullah menyatakan Fidusia adalah suatu perjanjian yang dimana perjanjian tersebut bersifat accesoir antara peminjam dan yang memberikan pinjaman (kreditur), yang dimana dalam suatu pernyataan pemimjam menyerahkan hak milik benda tersebut atas dasar mempercayai kepada kreditur untuk sebagai jaminan kredit yang diberikan. ${ }^{3}$

Praktiknya penggunaan fidusia yang paling banyak dijumapi dalam hal objek jaminan adalah kendaraan bermotor, maka peminjam tetap dapat memakai kendaraan bermotor yang dibebani dengan jaminan fidusia tersebut. Keuntungan yang diperoleh dari melakukan jaminan fidusia oleh pihak pemberi fidusia adalah tetap dapat memakai kendaraanya, sedangkan bagi penerima fidusia adalah mempunyai kedudukan sebagai kreditur preferen atau dengan kata lain, diutamakan dalam proses mendapatkan pelunasan. ${ }^{4}$

Ketentuan dalam UU JFDS memberikan pernyataan bahwa pembebanan benda fidusia dilakukan menggunakan akta notaris (yang kemudian disebut sebagai akta jaminan fidusia) dan selanjutnya melakukan pendaaftaran sebagaimana diatur dalam Pasal 11-18 UU JFDS.

\footnotetext{
1 Wijaya, Y. N. (2016). Perlindungan Hukum Bagi Debitur Jika Penghapusan Jaminan Fidusia Tidak Dilaksanakan Oleh Kreditur. Kumpulan Jurnal Mahasiswa Fakultas Hukum. hlm. 2.

2 Widyari, I. A. M., Sirtha, I. N., \& Sarjana, I. M. (2015). Akibat Hukum Pendaaftaran Jaminan Fidusia Dalam Sistem Online. Acta Comitas, hlm. 268-276.

3 Frieda Husni Hasbullah, 2009, Hukum Kebendaan Perdata, Hak-hak yang Memberi Jaminan Jilid 2, Jakarta, Indhill Co, hlm. 15.

${ }^{4}$ Diana, F., Rasyid, M. N., \& Azhari, A. (2017). Kajian Yuridis Pelaksanaan Penghapusan Jaminan Fidusia Secara Elektronik. Syiah Kuala Law Journal (SKLJ), 1(2), hlm 40.
} 
Terkait dengan pendaaftaran fidusia yang dilakukan secara online sesuai dengan surat edaran Diirektorat Jenderail Administrasi Hukum Umum (Ditjen AHU) pada tanggal 5 Maret 2013 Nomor AHU-06.OT.03.01 Tahun 2013 tentang Pemberlakuan Sistem Administrasi Pendaaftaran Jaminan Fidusia Secara Elektronik (Online System). Berdasarkan peraturan tersebut maka mulai dari tahun 2013, hal-hal yang berhubungan dengan pendaaftaran, perubahan dan penghapusan jaminan fidusia tidak lagi dilakukan Kantor Pendaaftaran Fidusia melainkan dilaksanakan secara sistem elektronik dengan mengakses www.fidusia.ahu.go.id., Sesuai dengan Peeraturan Pemeriintah Nomor 21 Tahun 2015 tentang Tata Cara Pendaftaran Jaminan Fidusia dan Biaya Pembuatan Akta Fidusia (selanjutnya disebut dengan PP FDS ). ${ }^{5}$

Dalam PP FDS ,mengharuskannya adanya pendaaftaran jaminan fidusia terdapat peraturan terkait penghapusan jaminan fidusia yang dilakukan setelah utang dari pemberi fidusia yang dijamin dengan jaminan fidusia tersebut selesai Ketentuan Pasal 16 ayat (1) PP FDS menentukan bahwa hapusnya jaminan fidusia adalah karena:

a. hapusnya utang yang dijamin dengan fidusia;

b. pelepasan hak atas jaminan fidusia oleh penerima fidusia; atau

c. musnahnya benda yang menjadi objek jaminan fidusia.

Pelaksanaan penghapusan jaminan fidusia yang melalui media elektronik yang dan dapat dilakukan di Notaris, Notaris juga diharuskan meningkatkan pelayanannya kepada masyarakat dalam rangka mendukung pertumbuhan ekonomi, dengan adanya suatu yang baru dalam era elektronik yang dimana dalam perkembangannya melahirkan konsep electronic notary dan cybernotary, ${ }^{6}$ karena dalam proses penghapusan jaminan fidusia hanya para Notaris yang sudah mendapatkan hak akses yang dapat login melalui website www.fidusia .ahu.go.id untuk melakukan proses penghapusan jaminan fidusia, Notaris disini di tunjuk sebagai kuasa dari penerima fidusia, yang di mana di jelaskan dalam PP FDS pasal 16 ayat (2) disebutkan“Dalam hal jaminan fidusia hapus sebagaimana dimaksud pada ayat (1) maka penerima fidusia, kuasa atau wakilnya, diwajibkan melakukan pemberitahuan kepada Mentri dengan cara melakukan penghapusan fidusia dan diberikan jangka waktu paling lama 14 (empat belas) hari semenjak tanggal selesainya jaeminan fidusia ."

Proses penghapusan jaminan fidusia memiliki arti penting. Karena tujuan melakukan penghapusan jaminan fidusia adalah demi tercapainya pelaksanaan PP FDS Pasal 16-17. Dengan dilakukannya penghapusan jaminan fidusia maka akan menjadikan benda tersebut bukan sebagai objek jaminan dari suatu utang dan sertifikat jaminan fidusia yang bersangkutan sudah tidak berlaku lagi dan selanjutnya diberikan sertifikat surat keterangan penghapusan jaminan fidusia. ${ }^{7}$

Dalam PP FDS tidak memberikan sanksi secara tegas bagi penerima fidusia, kuasa atau wakilnya bila tidak melakukan proses penghapusan jaminan fidusia. Hal ini dapat mengakibatkan banyaknya penerima fidusia yang baik karena tidak mengetahui adanya kewajiban proses untuk melakukan penghapusan jaminan fidusia atau maupun karena dengan sengaja tidak memperoses penghapusan jaminan fidusia setelah lunas perjanjian kreditnya. Dalam prakteknya banyak terjadi adalah ketika pemberi fidusia sudah melakukan pelunasan utangnya kepada penerima fidusia maka proses selanjutnya adalah penerima fidusia berkewajiban untuk melaksanakan proses penghapusan jaminan fidusia melalui website www.fidusia .ahu.go.id agar jaminan fidusia tersebut dihapuskan dari daftar

\footnotetext{
5 Siringoringo, E. V., Dharmawan, N. K. S., \& Agung, I. G. N. (2010). Keabsahan Pendaaftaran Fidusia Kendaraan Bermotor Secara Online Oleh PT. Federal International Finance Group (PT. FIF GROUP). hlm 3. 6 Edmon Makarim, 2012, Notaris dan Transaksi Elektronik: Kajian Hukum tentang Cybernotary atau Electronic Notary, Jakarta, Rajawali Pers, hlm 10.

7 PURBA, L. V. L., \& Fitriani, R. (2017). Penerapan Pencoretan (Roya) Jaminan Fidusia dalam Perjanjian Pembiayaan antara Perseroan Terbatas Pegadaian (Persero) dan Nasabah di Kota Pekanbaru. Jurnal Online Mahasiswa (JOM) Bidang Ilmu Hukum, 3(2), hlm 13.
} 
jaminan fidusia dan diterbitkan keterangan berupa sertifikat penghapusan jaminan fidusia yang menyebutkan bahwa jaminan yang bersangkutan sudah tidak berlangsung lagi. Dalam prakteknya kreditur sebagai pihak yang diberikan kewajiban, acapkali tidak melakukan kewajibannya tersebut. Seringkali kreditur hanya memberikan kembali bukti kepemilikan objek jaminan yang disertai dengan surat keterangan yang menyatakan lunas sebagai bukti bahwa utang debitur telah lunas dibayar, tetapi tidak disertai dengan sertifikat mengenai penghapusan jaminan fidusia. Dalam hal ini pemberi fidusia menjadi pihak yang dirugikan karena sesuai dengan ketentuan Pasal 17 ayat (2) PP FDS menentukan bahwa : Jika penerima fidusia, kuasa atau wakilnya tidak melakukan proses penghapusan jaminan fidusia sebagaimana diatur dalam Pasal 16 PP FDS, jaminan fidusia yang dimiliki oleh pemberi fidusia tidak dapat didaftarkan kembali sebagai jaminan fidusia.

Berdasarkan ketentuan tersebut dapat menimbulkan status dan kedudukan objek jaminan fidusia yang telah luna namun belum dilakukan proses pemberitahuan penghapusan jaminan fidusia sebagaimana telah jelaskan, dapat memberikan kerugian bagi pemberi fidusia yang tidak dapat melakukan pendaftaran kembali sebagai objek jaminan fidusia dengan utang yang berbeda yang akan didaftarkan dikemudia hari. Kewajiban melakukan penghapusan jamiena fidusia merupakan kewajiban penerima fidusia, bukanlah kewajiban pemberi fidusia, akibat yang akan ditimbulkan dikemudia hari yang akan menanggung atas kelalaian penerima fidusia adalah pemberi fidusia. permasalahan yang di kaji dalam tulisan ini berfokus kepada: Bagaimana pelaksanaan ketentuan penghapusan jaminan fidusia di kantor Notaris di Kabupaten Badung, dan bagaimana akibat hukum apabila tidak dilakukannya penghapusan atas jaminan fidusia.

\section{Metode Penelitian}

Jenis penelitian di dalam jurnal adalah dengan penelitian hukum empiris, yang dimana dalam proses mengumpulkan datanya menggunakan dua teknik, yaitu teknik studi dokumen dan teknik wawancara. Bila keseluruhan data yang dicari telah terkumpul baik melalui studi kepustakaan ataupun dengan wawancara para narasumber, selanjutnya data-data tersebut akan diproses dan dianalisis secara kualitatif dengan begitu dapat menghubungkan data-data yang sudah ada untuk selanjutnya dilakukan proses secara deskriptif kualitatif dan sistematis. Tujuan studi ini, yakni untuk menganalisis secara kritis Pelaksanaan ketentuan penghapusan jaminan fidusia secara sistem online di Kabupaten Badung dan bagaimana akibat hukum bila tidak dilakukanya proses penghapusan jaminan fidusia setelah dilakukan pelunasan. Jenis penelitian yang digunakan di dalam menanggapi permasalahan yang dimaksud adalah dengan penelitian hukum empiris, yang mana di dalam penelitian ini terdapat perbedaan antara das sollen dan das sein yaitu perbedaan antara teori atau peraturan yang sudah ada dan kenyataan/pelaksanaanya, yaitu adanya kesenjangan antara UU JFDS Pasal 25 tentang hapusnya Jaminan fidusia dan PP FDS Pasal 16 - 17 tentang hapusnya Jaminan Fidusia.

\section{Hasil Dan Pembahasan}

\subsection{Bagaimana Pelaksanaan Ketentuan Penghapusan Jaminan Fidusia Di Kantor Notaris Di Kabupaten Badung}

Dimulai dari terbitnya Peraturan Menteri Hukum dan Hak Asasi Manusia Republik Indonesia Nomor 9 Tahun 2013 tentang Pemberilakuan Pendafitaran Jaminan Fidusia secara Elektronik adalah dasar dari terbentukanya pelaksanaan pendaftaran fidusia dan penghapusan jaminan fidusia melalui online sistem yang dimana dianggap penting untuk meningkatkan pelayanan jasa hukum dalam proses pendaftaran fidusia dan penghapusan fidusia dengan cepat, murah dan cepat. ${ }^{8}$

8 Lalo, R. 2019. Tinjauan Yuridis Pelaksanaan Pendaaftaran Jaminan Fidusia Secara Elektronik (Online). 
Selanjutnya dalam PP FDS Pada pasal 16 sampai Pasal 17 tentang penghapusan jaminan fidusia, dijelaskan bahwa dalam hal proses penghapusan jaminan fidusia harus diberitahukan dalam jangka waktu 14 (empat belas) hari sejak tanggal hapusnya atau lunasnya jaminan fidusia, yang dimana yang memiliki kewajiban untuk melaporkannya adalah penerima fidusia, kuasa atau wakilnya wajib memberitahukan kepada Mentri hukum dan hak asasi manusia.

Dalam pelaksanaannya penerima fidusia yang wajib melaporkan penghapusan jaminan fidusia, tetapi untuk melakukan penghapusan jaminan fidusia, penerima fidusia membutuhkan Notaris sebagai kuasanya untuk melakukan proses penghapusan fidusia. ${ }^{9}$ Pada Pasal 1792 KUHPerdata, yang dimaksud pemberian kuasa adalah suatu kehendak suatu orang yang diperuntukan kepada orang lain yang diamana dalam hal ini memberikan kuasa untuk melakukan sesuatu urusan tertentun.10 Rumusan pada Pasal 1792 KUHPerdata memberikan rumusan bahwa suatu kuasa adalah suatu perjanjian antara satu orang dengan orang lain untuk melakukan kehendak melakukan sesuatu tertentu. Berdasarkan ketentuan Pasal 1313 KUHPerdata dimana suatu perjanjian adalah perbuatan mengikatkan diri terhadapat satu orang lainya atau lebih. Oeh dasar itu pemberian kuasa terhadap Notaris merupakan suatu perjanjian, maka syarat-syarat sahnya dalam perjanjian juga berlaku dalam pemberian kuasa tersebut.

Kuasa pada hakekatnya diperuntukan untuk melakukan hal-hal yang bersifat pengurusan, namun kuasa juga dapat diberikan sebagai bagian dari suatu perjanjian untuk melakukan jasajasa tertentu. Jika pemberian kuasa diberikan sebagai bagian dari perjanjian, surat kuasa yang mengatur tentang pemberian kuasa harus ditandatangani oleh pemberi dan penerima kuasa. Dalam hal ini, berarti Notaris dapat melakukan penghapusan jaminan fidusia secara elektronik (online system) jika adanya pemberian kuasa dari penerima fidusia (sebagai pemberi kuasa) berdasarkan perjanjian pemberian kuasa yang dituangkan dalam surat kuasa yang telah ditandatangani oleh kedua belah pihak.

Pada PP FDS pasal 16 ayat (2) terdapat kewajiban memberitahukan kepada mentri bila jaminan fidusia tesebut hapus, dalam hal memberitahukan kepada Mentri dapat membuka melalui https://fidusia .ahu.go.id, dalam hal ini Notaris dapat mengakses website tersebut untuk melakukan proses penghapusan jaminan fidusia. Notaris yang akan melakukan proses penghapusan jaminan fidusia secara online dengan menginput data yang tertera dalam Sertifikat jaminan fidusia yang diberikan, mengingat hak akses untuk username dan password untuk login dan seterusnya masuk ke dalam menu layanan penghapusan jaminan fidusia secara online yang hanya dimiliki oleh seorang Notaris. Di Kabupaten Badung terdapat 155 kantor Notaris yang dimana dalam penelitian ini akan ada 5 (lima) Notaris yang akan di jadikan narasumber, yang selanjutnya di wawancara untuk mendapatkan informasi mengenai pelaksanaan ketentuan penghapusan jaminan fidusia di kantor Notaris di Kabupaten Badung. Dalam wawancara kepada 5 (lima) Notaris yang wilayah kerjanya di Kabupaten Badung, dalam prakteknya Notaris berlokasi di kabupaten badung sudah melaksanakan penghapusan fidusia secara online system sesuai dengan peraturan yang berlaku, namun dalam pelaksanaan proses penghapusan fidusia online belum ada kesadaran oleh penerima fidusia maupun pemberi fidusia untuk melakukan penghapusan jaminan fidusia, meski dalam PP FDS pada Pasal 16-17 telah dijelaskan secara jelas agar melakukan proses penghapusan jaminan fidusia agar tidak terjadi kerugian pada pihak pemberi fidusia.

\subsection{Bagaimana Akibat Hukum Bila Tidak Dilakukan Penghapusan Jaminan Fidusia}

Lex Privatum, 7(1), hlm 121.

9 Felisa, A. 2018. Fungsi Notaris Dalam Penghapusan Jaminan Fidusia Secara Elektronik. Jurnal Media Hukum Dan Peradilan, 4(2), hlm 25-26.

10 Salim H.S, 2009, Hukum Kontrak TeoriETeknik Penyusunan Kontra, Jakarta, Sinar Grafika, hlm 84. 
Dalam hal ketentuan Pasal 4 UU JFDS, perjanjian jaminan fidusia merupakan bentuk perjanjiian tambahan atau perjanjian ikutan yang memiliki sifat keterkaitan dengan perjanjian pokoknya. Perjanjian ikutan tidak pernah muncul apabila perjanjian pokoknya tidak ada. Apabila perjanjian pokoknya telah hapus selanjutnya perjanjian ikutan atau tambahannya akan mengikuti hapusnya, akan tetapi bila perjanjian tambahanya atau perjanjian ikutannya hapus. perjanjian pokoknya akan tetap ada, apabila utang tersebut belum lunas. ${ }^{11}$

Terdapat beberapa keadaan yang menyebabkan hapusnya jaminan fidusia, disebutkan pada ketentuan Pasal 16 ayat (1) PP FDS yang menentukan bahwa hapusnya jaminan fidusia dapat disebabkan karena 3 (tiga) hal, yaitu karena hapusnya hutang yang dijamin dengan fidusia, karena pelepasan hak atas jaminan fidusia oleh penerima fidusia atau karena musnahnya benda yang menjadi objek jaminan fidusia.

Pengaturan proses penghapusan jaminan fidusia dapat dilihat dalam UU JFDS dan PP FDS, namun dalam peraturan terdapat beberapa perbedaan. Dalam UU JFDS yang disebutkan subjek yang melakukan proses penghapusan adalah peneerima fidusia, namum dalam PP FDS disebutkan lain, dalam Pasal 16 ayat (2) kewajian dalam hal proses penghapusan jaminan fidusia tidak hanya dapat dilakukan oleh penermia fidusia namun dapat dilakukan oleh kuasa atau wakil dari pihak peneriima fidusia .

Menurut pendapat D.Y. Witanto bahwa surat keterangan lunas yang diberikan oleh pihak penerima fidusia dapat dipakai sebagai dasar menolak permohonan eksekusi dari pihak penerima fidusia jikalau pihak penerima fidusia melaksanakan kekuatan eksekutorial yang terdapat dalam sertifikat jaminan fidusia. ${ }^{12}$

Ketentuan dalam peraturan PP FDS yang memberikan keharusan untuk melakukan proses pemberitahuan tentang lunasnya jaminan fidusia, telah memberikan ketentua yang lebih tegas dibandingkan dengan ketentua dalam UU JFDS yang dimana tidak memberikan adanya keharusan untuk melakukan penghapusan jaminan fidusia dan seolah-olah hanya bersifat sebagai anjuran untuk melakukan proses penghapusan jaminan fidusia. Dalam PP FDS tidak memberikan sanksi apapun apabila penerima fidusia, kuasa atau wakilnya tidak melakukan proses penghapusan jaminan fidusia. Tidak adanya sanksi yang tegas menyebabkan penerima fidusia, kuasa atau wakilnya tidak memiliki kewajiban untuk melakukan proses penghapusan jaminan fidusia yang telah lunas.

Proses penghapusan jaminan fidusia harus dilakukan terutama bila objek kendaraan tersebut di jaminkan kepada lembaga jaminan yang sewaktu melakukan pembebanannya fidusia disyaratkan untuk melakukan kewajiiban pendaftaran di sistem online. Proses penghapusan yang paling diketahui oleh masyarakat adalah pada hak tanggungan, setelah hutangnya lunas maka hak tanggungan hapus dan perlu untuk dilakukan penghapusan (roya atau pencoretan) agar tanah yang semula dibebani dengan hak tanggungan menjadi bersih dari statusnya sebagai jaminan.

Pada prakteknya penerima fidusia banyak yang tidak melakukan proses penghapusan jaminan fidusia, karena banyak yang beranggapan apabila utang tersebut telah dilunasi maka akan turut hapus pembebanan jaminan fidusia tersebut dan maka dari itu tidak perlu lagi melakukan proses penghapusan jaminan fidusia. Pihak peenerima fidusia dalam prakteknya juga menyatakan bahwa mereka tidak mengetahui adanya sanksi bilamana belum dilakukan proses penghapusan, maka akibatnya benda yang di jadikan objek jaminan fidusia tersebut tidak dapat didaftarkan kembali. Berdasarkan pelaksaan peraturan di lapangan, pada saat

11 Adawiyah Nasution, S. H., \& Kn, M. 2018. Pelunasan Hutang Terhadap Jaminan Fidusia . Jurnal Hukum Kaidah: Media Komunikasi dan Informasi Hukum dan Masyarakat, 17(3), hlm. 116.

${ }^{12}$ Y. Witanto, 2015, Hukum Jaminan Fidusia dalam Perjanjian Pembiayaan Konsumen (Aspek Perikatan, Pendaaftaran dan Eksekusi), Bandung, PT. Mandar Maju, hlm. 145. 
penelitian ini, proses pendaaftaran jaminan fidusia untuk objek yang belum dilaksanakan proses penghapusan masih dapat dilakukan pendaftaran kembali dan tidak pernah terjadi penolakan oleh sistem fidusia elektronik tersebut.

Ketentuan pada Pasal 16 ayat (2) PP FDS menentukan adanya ketentuan mewajibkan untuk melaporkan kepada kementrian bilamana pembebanan objek jaminan fidusia telah lunas atau berakhir, agar dapat dipergunakan dikemudian hari untuk menjadi objek jaminan fidusia di penerima jaminan fidusia yang lain. Dalam hal melakukan pendaaftaran jaminan fidusia ulang maka benda yang dijaminkan yang belum di lakukan penghapusan fidusia tidak dapat di daftarkan, sesuai dengan PP FDS Pasal 17 ayat (2). ${ }^{13}$ Pada prakteknya pendaftara fidusia ulang yang dimana objek fidusia memiliki nomor BPKB (buku pemilik kendaraan bermotor), nomor mesin, nomor rangka yang sama, nama pemilik yang sama dan belum di lakukan penghapusan jaminan fisdusia masih dapat di daftarkan, tidak ada suatu peringat oleh sistem fidusia bahwa benda yang akan di bebankan jaminan fidusia masih belum dilakukan pelunasan atau penghapusan jaminan fidusia.

\section{Kesimpulan}

Pelaksanaan penghapusan jaminan fidusia yang dilakukan oleh notaris di kabupaten badung sudah terlaksana sesuai dengan PP FDS Pada pasal 16 sampai Pasal 17 tentang penghapusan jaminan fidusia, yang dimana peran notaris dalam proses penghapusan adalah sebagai kuasa dari debitur maupun kreditur untuk melakukan penghapusan jaminan fidusia yang dimana dalam PP FDS penghapusan jaminan fidusia di wajibkan agar tidak terjadinya fidusia ulang, yang dapat menyebabkan tidak bisa didaftarkan kembali sebagai objek jaminan fidusia, tapi dalam prakteknya banyak perjanjian fidusia yang didaftarkan oleh kreditur yang tidak dilakukan penghapusan jaminan fidusia pada saat utang debitur telah lunas, dan dalam prakteknya banyak obyek jaminan fidusia yang telah di daftarkan (belum dilakukan pengahpusan jaminan fidusia) dapat dilakukan pedaftaran kembali, di sini lah seharusnya sistem pendaftaran fidusia online dapat mencegah secara langsung agara tidak terjadinya jaminan fidusia yang di lakukan berulang-ulang tanpa melakukan penghapusan jaminan fidusia melalui online sistem. Kementrian Hukum dan Hak Assai Manusia hendaknya membuat suatu sistem warning dalam hal pendaftaran fidusia online yang dimana dalam sistem tersebut dapat menditeksi suatu obyek fidusia yang telah di daftarkan agar tidak dapat didaftarkan ulang sebelum dilakukan penghapusan jaminan fidusia sesuai dengan PP FDS, dan seharusnya terdapat sanksi yang tegas bila kreditur ataupunn debitur yang tidak melakukan penghapusan jaminan fidusia dengan PP FDS, dan seharusnya terdapat sanksi yang tegas bila kreditur ataupunn debitur yang tidak melakukan penghapusan jaminan fidusia.

\section{Daftar Pustaka / Daftar Referensi}

\section{$\underline{\text { Buku }}$}

Edmon Makarim, 2012, Notaris dan Transaksi Elektronik: Kajian Hukum tentang Cybernotary atau Electronic Notary, Jakarta, Rajawali Pers.

Frieda Husni Hasibullah, 2009, Hukum Kebendaan Perdata, Hak-hak yang Memberi Jaminan Jilid 2, Jakarta, Indhill Co.

Y. Witanto, 2015, Hukum Jaminan Fidusia dalam Perjanjian Pembiayaan Konsumen (Aspek Perikatan, Pendaaftaran dan Eksekusi), Bandung, PT. Mandar Maju.

Salim H.S, 2009, Hukum Kontrak Teori\&Teknik Penyusunan Kontra, Jakarta, Sinar Grafika.

\footnotetext{
${ }^{13}$ Winstar, Y. N., \& Harahap, I. (2017). Pelaksanaan Roya Atas Benda Bergerak di Kota Pekanbaru. Jurnal Hukum Respublica, 16(2), hlm 226.
} 


\section{$\underline{\text { Jurnal }}$}

Widyari, I. A. M., Sirtha, I. N., \& Sarjana, I. M. 2015. Akibat Hukum Pendaaftaran Jaminan Fidusia Dalam Sistem Online, Acta Comitas Volume II nomor 2 Agustus 2017.

Lalo, R. 2019. Tinjauan Yuridis Pelaksanaan Pendaaftaran Jaminan Fidusia Secara Elektronik (Online). Lex Privatum, Volume I nomor 1 Januari-Maret 2013.

Felisa, A. 2018. Fungsi Notaris Dalam Penghapusan Jaminan Fidusia Secara Elektronik. Jurnal Media Hukum Dan Peradilan, Volume 4 nomor 2 October 2018.

Adawiyah Nasution, S. H., \& Kn, M. 2018. Pelunasan Hutang Terhadap Jaminan Fidusia . Jurnal Hukum Kaidah: Media Komunikasi dan Informasi Hukum dan Masyarakat, Volum 17 nomor 3 tahun 2018.

Diana, F., Rasyid, M. N., \& Azhari, A. (2017). Kajian Yuridis Pelaksanaan Penghapusan Jaminan Fidusia Secara Elektronik. Syiah Kuala Law Journal (SKLJ), 1(2), Volume 1 nomor 2 Agustus 2017.

Wijaya, Y. N. (2016). Perlindungan Hukum Bagi Debitur Jika Penghapusan Jaminan Fidusia Tidak Dilaksanakan Oleh Kreditur. Kumpulan Jurnal Mahasiswa Fakultas Hukum, Tahun 2017

Winstar, Y. N., \& Harahap, I, (2017). Pelaksanaan Roya Atas Benda Bergerak di Kota Pekanbaru. Jurnal Hukum Respublica, 16(2), Volume 16 nomor 2 Mei 2017.

Siringoringo, E. V., Dharmawan, N. K. S., \& Agung, I. G. N. (2010). Keabsahan Pendaaftaran Fidusia Kendaraan Bermotor Secara Online Oleh PT. Federal International Finance Group (PT. FIF GROUP), Volume 03 nomor 03 Mei 2015.

\section{Peraturan Perundang-undangan}

Kitab Undang-Undang Hukum Perdata.

Undang-undang Nomor 42 Tahun 1999 tentang Jaminan Fidusia (Lembaran Negara Republik Indonesia Tahun 1 Undang-Undang Nomor 4 Tahun 1996 tentang Hak Tanggungan (Lembaran Negara Republik Indonesia Tahun 1996 Nomor 42, Tambahan Lembaran Negara Republik Indonesia Tahun 1996 Nomor 3632).

Undang-undang Nomor 2 Tahun 2014 perubahan atas undang-undang Nomor 30 Tahun 2004 tentang Jabatan Notaris (Lembaran Negara Republik Indonesia Tahun 2014 Nomor 3, Tambahan Lembaran Negara Republik Indonesia Nomor 5491).

Peraturan Pemerintah Republik Indonesia Nomor 21 Tahun 2015 tentang tata cara pendaaftaran jaminan fidusia dan biaya pembuatan akta jaminan fidusia (Lembaran Negara Republik Indonesia Tahun 2015 Nomor 80, Tambahan Lembaran Negara Republik Indonesia Nomor 5691).

Surat Edaran direktur jendral Administrasi hukum umum Nomor AHU-01.OT.03.01 Tahun 2013 tentang pemberlakuan sistem administrasi pendaaftaran jaminan fidusia secara elektronik. 